\title{
PARTICIPATION OF EMPLOYEES IN MANAGEMENT BODIES OF THE MACEDONIAN SHAREHOLDING COMPANIES
}

\author{
PhD Ljupcho Petkukjeski
}

Adjunct teacher at the School of Law within University American College Skopje, Macedonia, "Treta

Makedonska Brigada" 60, 1000, Skopje,

e-mail: petkukeskiljupco@yahoo.com

PhD Marko Andonov

Assosisate Professor at the School of Law within the University American College Skopje, st."Treta

Makedonska Brigada" 60, 1000, Skopje,

e-mail: andonov@uacs.edu.mk

PhD Zoran Mihajloski

Assosisate Professor at the School of Law within the University American College Skopje, st. "Treta

Makedonska Brigada" 60, 1000, Skopje,

e-mail: mihajloski@uacs.edu.mk

PhD Kate Trajkova

Adjunct teacher at the School of Law within the University American College Skopje, Macedonia, "Treta

Makedonska Brigada" 60, 1000, Skopje,

e-mail:k_trajkova@yahoo.com

PhD Samir Ljativ

Adjunct teacher at the School of Law within University American College Skopje, Macedonia, "Treta

Makedonska Brigada" 60, 1000, Skopje,

e-mail: latifs@winrock.org

\section{ABSTRACT}

Joint Stock Company is a company in which shareholders participate with investments in the nominal capital which is divided into shares and the shareholders are not liable for the obligations of the company.

Modern joint-stock companies are companies with enormous economic and other powers. Concentration of capital and labor of these companies gives them a very strong position in the market through which these companies have great impact on the economic and political relations as well as on the social situation in the society.

Besides the managing bodies (members of the supervisory bodies and non-executive members), the bodies of management - management (executive directors, board members and other senior workers - managers), shareholders and employees also are participants in the organization of the company. Each of the participants, including employees has its place and its role within the activity of the enterprise.

Employees are one of the most important factors involved in the realization of the business venture and in the creation of new value of the company (profits). As a real consequence of this fact arises the question of their participation in decisions about the distribution of newly created value, which can lead to a possible conflict with investors and managers of the company.

With the participation of employees in the bodies of the shareholders company and in decision-making of importance to the company, they protect their primarily economic and social rights and interests, and with this, they contributes to economic and social peace and stability in the company.

The main goal of this paper is to give the legal basis for the practical realization of the right of participation of employees in the management of the share holders company in the Republic of Macedonia.

Keywords: participation, joint stock company, managing bodies, employees

SUBJECT CLASSIFICATION: $\mathrm{K}-22$

\section{Academic Discipline And Sub-Disciplines}

Law and Business Law

\section{METHOD}

Comparative Method; Law Method; Literary Analysis 


\section{INTRODUCTION}

The issues of participation of the employees in the management of the shareholder company, together with issues of the informing and consultation of the employees are directly related to the totality of relations to the issues of participations of employees in the management and in the decision - making with enterprise (company). These are very topical issues that are accomplished through various forms and at various levels.

The various systems, i.e. countries have different solutions. Somewhere these issues are regulated by law, somewhere in the collective agreement and the like.

The main objective of the issues of participation of employees in the management of the shareholders company, together with issues of information and consultation of employees, is the realization of the right of participation broadly. On the other hand the ultimate goal is the integration of employees as important participants in the enterprise (company) in the realization of the business venture of the enterprise (company) and of course in the realization of economic and social rights and the interests of the employees.

The relations between labor (the employees) and the capital (investors (shareholders, owners of shares) are always opposed and are potential reason for conflict between them. The modern societies approach finding legal solutions by the law, which will bring to the holders of the business venture industrial or social peace, by the other hand for providing conditions that will help to avoid possible collision and side effects. In this regard, the mechanisms of participation of employees in the management of the company are very important forms of employee participation in the processes of decision making and management of the company. Through these forms also the employees can become part of the power relationships in making decisions of importance to the shareholder company.

\section{DEFINITION OF PARTICIPATION}

The participation of employees means any mechanism, including information, consultation and participation, through which employees' representatives may influence the decision-making in the company.

Thus the general definition includes virtually all means of achieving the participation as employee participation in decisionmaking through direct decision-making, and through indirect influence through information, counseling and negotiation, further includes the forms of participation of employees in decision-making that can be institutionalized through special body - works council, participation in supervisory and management boards of companies, specialized participation on specific issues as safety and health at work etc. , then various informal forms of participation through the establishment of ad hoc advisory bodies, material employee participation, for example through participation in the distribution of investment income, the income or profits.

\subsection{Participation of the Employees in the Supervisory or the Management Boards of the Shareholder Company}

According to the Fifth Directive on the structure of the shareholder companies and the obligations of their organs, the management of the company may be organized according to the one - tier system (board of directors) or two-tier system (management board and supervisory board). The company itself selects the management system. With changes of the statute the one - tier system can be replaced with a two-tier and back.i According to this directive as regards the management of the company, complete freedom is left to states members to choose the management model. Thus, States Members can determine by whether the management in the companies will be organized according to the two-tier system (management board and supervisory board) or according the one-tier system of management (Board of Directors).

The Board of Directors or The Management board within the powers defined by law and statute and the powers expressly granted by the assembly, manage with the company. The Board of Directors or The Management board have the broadest powers in the management of the company in the case of the company's operations and actions and in all circumstances on behalf of the company. Oversight over the work of the executive members of the board of directors are performing the non-executive members, and the oversight over the work of the Board of Directors is managed by the Supervisory board.

The role of the organs in the management of the company is to manage the company. The consequence of the strengthening of the representatives of labor (workers) and their effect in terms of the strength of investors and managers, primarily needed for reducing the possible conflicts between labor and capital relations and working with the company, and participation of employees is included in the work and decision making bodies of the management company. Employees have the opportunity to choose their representatives in the management board and the supervisory board of the company.

According to the Council Directive 2001/87 / EC of 8 October 2001 on supplementing the Statute of the European company in terms of participation of the workers, and participation of employees in the management with the company which means influence of the body representative of the employees and / or workers' representatives in the affairs of the company through the right to elect or appoint some of the members of the company's supervisory or management board, or the right to propose and / or oppose the application of some or all members of the supervisory or management board of the company. 


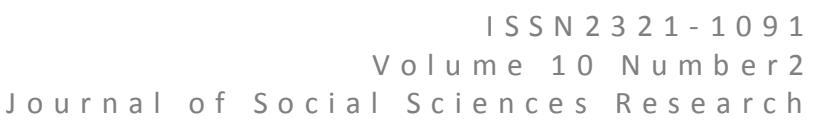

This kind of participation represents a direct and immediate decision of the employee representatives on all matters pertaining to the jurisdiction of these authorities to manage the company. In this case, despite the dominant participation of investors (shareholders, owners of shares) in these organs and their decisive role in making decisions, employee representatives have the opportunity to get to know and to decide directly on all matters of greatest importance to the work of the company, including the issues of economic and social nature for employees.

The representatives of the employees in the management company, appoints and dismisses the members of the representative body of workers. If in the enterprise the representative body is un-institutionalized or if there is a special representative of the employees, the election and revocation of representatives of employees is made by all employees in a manner in which the selection is made by the representative body of employees.

Employee representatives participate in deciding like members of certain organs of management or supervision of the company. In that case we have three specific cases: 1) employee representatives to be in the minority; 2) representatives of employees to be represented in equal numbers with others; and 3) employee representatives to represent the majority, to be only represented in the bodies who decide. ${ }^{v}$

Representatives of the employees are participating in the various organs of management or supervision of the company. They participate in decision making. However, there are significant differences in the method of incorporating employees representatives in the governing bodies of companies and enterprises, and in terms of their status, scope and character of their authority. Thus, participation in the supervisory boards of shareholder companies is provided in many countries in Europe, of which will be mentioned in particular: Germany, France, Austria, Luxembourg, Netherlands. While for example in Norway and Sweden there is a possibility of including employee representatives on boards of companies. Employee participation is regulated in almost all countries when it comes to public companies, regardless of the form in which they exist." $^{\text {v }}$

\section{LAW ON TRADE COMPANY BY $1996^{\text {vii }}$}

Law on Trade Company by $1996^{\text {viii }}$ is the most important legislative project implemented after the adoption of the Constitution of 1991. With this law began the process of constitution of commercial law, and in those frameworks the right of companies in the country, in which the system of Republic of Macedonia was granted the status of an autonomous branch of law.

Law on Trade Company by 1996 was the first law that started arranging the issue of employee participation in management and decision making in enterprises in the social - economic system based on private ownership, entrepreneurship and market. This law regulates only the participation of employees in companies that are organized in the form of companies, and not settled the question of employee participation in the management of public enterprises and institutions. Employee participation was regulated only in the companies organized as a single system of management (Board of Directors) and a two-tier management system (Management board and Supervisory board). The exact participation of employed in the structure of non-executive members of the board of directors or the supervisory board was an optional possibility depended on the regulation of issue with the statute of the shareholder company. ${ }^{x}$

\subsection{Participation of the Employees in the Management of Shareholder Company in which the Management is Organized According to the One - Tier System of Management - Board of Directors}

\subsubsection{Appointment of Non-executive Members of the Board of Directors by Employees}

The possibility of employees participation in enterprise management are realized through certain conditions prescribed by the Companies Law. The first condition that needed to be filled was that the corporation must have at least 300 or more employees, and the second was that the possibility should be provided in the statute of the company. Additionally the law anticipates a possibility that the majority of employees should react and speak out against the appointment of members of the Board of Directors among their ranks. ${ }^{x i}$ The number of the participants who would be appointed from the employees was one quarter meanwhile the shareholders of the company would appoint three quarters from the board of directors. ${ }^{\text {xi }}$ The way of appointing the non - executive members from the employees was regulated in the statute of the company. ${ }^{\text {xiii }}$

\subsubsection{Conditions under which Non - Executive Members are Appointed by the Employees}

For appointing a non - executive member of Board of Directors, employees can appoint only a person who was permanently employed in the company. The person who could be appointed had to have at least two years working experience in the company. They can step aside from that condition only if the company was founded less than two years. ${ }^{\text {xiv }}$

Candidates for non - executive members of the Board of directors which were elected from the employees of the company could propose one fifth of the employees in the company or if the number of the employees was bigger than two thousand, 100 employees, also the Council of the employees. ${ }^{\mathrm{x}}$

The non - executive member of the Board of Directors, whether was appointed by employees, at the same time could not be appoint in more than five boards of directors with headquarters in the Republic of Macedonia. ${ }^{x v i}$ 


\subsubsection{Mandate of Non - executive Members Appointed by the Employees}

The mandate of the non - executive members of the Board of directors appointed by the employees is determined by the company statue and couldn't last longer than six years. The mandate could be renewed if in the company statute was not otherwise specified.

The non - executive members who were appointed by the employees retain employment rights and their rewards in the capacity of employees couldn't be reduced due to their function as non - executive members of the Board of directors.

Termination of employment of an employee in the company, represents the legal basis of the termination to his function as non - executive member of the Board of directors. Except in case of termination of the employment requested by the employee, the decision on termination of the employment as a non - executive member of the Board of directors appointed by the employees could be brought after a lawsuit in the competitive Court. ${ }^{\text {xii }}$

\subsubsection{Protection of the Employment Rights of Non - Executive Members Appointed by the Employees}

The non - executive members appointed by the employees have full protection on their employment rights. After the appointment by the employees these persons weren't losing their employment rights. ${ }^{\text {xiii }}$

The employment of the non - executive member in the Board of directors appointed by the employees couldn't stop against his will. Decision for terminating the employment of a non - executive member of the Board of Directors appointed by the employees could not bring any organ in the company who is authorized for establishment and termination of the employment. Decision for termination of employment, except when the case of termination is requested by the employee, during his mandate it would be claimed only by the court. ${ }^{\text {xix }}$

\subsubsection{Termination of the Mandate of the Non - Executive Member Appointed by the Employees}

The mandate of a non - executive member of the Board of directors appointed by the employees can be terminated in the fallowing cases : a) resignation b) termination of employment of the employee in the company, and c) expiration of the mandate for which it was appointed. Also in case when was made a decision for termination of the employment of an employee in a lawsuit at the competent court, the mandate of the non - executive member of the Board of directors was ended.

The law regulates the issue of dismissal on non - executive member. Non - executive member could be dismissed at any time by those who nominated him - the employees. The dismissal is made by the same procedure as the appointed is made. Specific terms for the appointment and dismissal of the non - executive members appointed by the employees are arranged in the company statute.

\subsubsection{Rights and Obligations of a Non - Executive Member Appointed by the Employees in the Board of Directors}

The Board of directors, within the jurisdiction lays down in the articles of incorporation of the company, statute, the law and the powers expressly granted by the general meeting of the company, has the broadest power to act in all circumstances on behalf of the company. ${ }^{x x i}$

Within the authority of the Board of directors, the member of the Board appointed by the employees had the same rights and obligations as the other non - executive members appointed by the shareholders. Non - executive member appointed by the employees was obliged to perform all the functions in the interest of the employees and the shareholders, also to keep in secret all the confidential reports which in any way are related to the company.

They also have the right for inducement for their work, without the approval of the non - executive members they must not complete any function or activity in other company, paid or not, on their behalf or on behalf of another person, had an obligation to take care of the conflict of interests, had the right to participate in decision making in the Board of directors, had an obligation to perform his duties with due care and diligence, in case of a violation of its obligations he responds to the company for the caused damage as solid obligor with the other members of the Board of directors, unless it proves that in doing his obligations acted with due care and diligence. ${ }^{\text {xxiv }}$

\subsection{Employee Participation in the Management Shareholder Company Organized under the Two - Tier Management system}

\subsubsection{Participation in the Supervisory Board}

The right of employees to participate in the management of the companies organized under the two - tier system, regarding the Supervisory board would be possible only in the companies that employ 300 or more people. Increase or decrease in the average number of employees in the company under or over 300 employees did not affect the stipulation of the law as long as the average number exceeded or fell below 300 employees over a period of two consecutive years. ${ }^{x \mathrm{v}}$ 


$$
\begin{array}{r}
\text { ISSN2321-1091 } \\
\text { JoIume } 10 \text { Number } 2 \\
\text { Journal of Social Sciences Research }
\end{array}
$$

Despite this requirement, the right to employee participation in the Supervisory board was conditional upon its establishment as an opportunity by the Company statute. Highlights of this opportunity in the Company Statute did not mean an automatic implementation. The law provides opportunity the majority of employees at the company to be able to stand up and to make the appointing members to the Supervisory board to be impossible on their part. $\times \times$ ii

In the companies in which in the Supervisory board participated the employees, the General meeting appointed three quarters of the members in the Supervisory board, and the employees of the company may appoint up to one quarter. $x \times$ vii

\subsubsection{Terms of Appointment and Mandate of the Members of Supervisory Board Appointed by the Employees}

A member of the supervisory board of the employees could be appointed only if it's a business capable natural person. Supervisory board members are appointed for a period which couldn't be longer than six years when they were appointed in the General meeting of the company, by the employees, not more than four years ago when they were appointed by the Company statute. Members of the Supervisory board may be reappointed without limitation on the possibility of re election. ${ }^{x x v i i i}$

\subsubsection{Structure of Non - executive Members Appointed by the Employees and the Manner of their Election}

The number of the Supervisory board members appointed by the employees couldn't exceed three (3). If the number of the Supervisory board members appointed by the employees was equal or greater that two (2), professionals, (engineers, professionals, etc.) selects at least one member of the supervisory board. The procedure for appointing, the rights to appoint, manner of appointment, duration and conditions for the mandate, dismissal and protection, as well as the employment contract in appointing the members of the board of directors by employees apply legal stipulations regarding the appointment of members of this body by the shareholders. ${ }^{x x i x}$

\subsubsection{Protecting the Employment Rights and the Rights of the Non - Executive Members Appointed by the Employees}

The members of the Supervisory board as non - executive members of the board of directors, appointed by the employees had full protection of their employment rights. After their appointing these persons weren't losing the employment rights. They continued further to carry out their duties and on that basis to exercise all their employment rights. Their reward in the capacity of employees or any other right couldn't be reduced due to perform the function as members of the Supervisory board. $x \times x$

The employment of member of the supervisory board appointed by the employees couldn't stop against its will. Decision on termination of employment of a member of the Supervisory board appointed by the employees couldn't bring neither the board of directors nor any other authority in the company that is authorized for establishment and termination of the employment, except in case of termination of the employment at the request of the employee, during his mandate, after submitting a lawsuit could be made only by the court.

\subsubsection{Termination of the Mandate of a Member of the Supervisory Board Appointed by the Employees}

The mandate of a member in the Supervisory board appointed by the employees can be terminated in the following cases: if resign, in on any basis his employment is terminated, as well as the expiry of the mandate for which it was named.

Termination of employment was ground for termination of his mandate as member of the Supervisory board appointed by the employees. Dismissal of a member of the Supervisory board appointed by the employees can be possible after submitting a law suit in front of the court.

Dismissing a member of the Supervisory board is regulated with the Company Law. The member of the supervisory board appointed by the employees could be dismissed at any time by those who appointed them. The specific provisions on the issue of the supervisory board appointed by the employees are provided in the Company Statute.

\subsubsection{Rights and Obligations of a Member of the Supervisory Board Appointed by the Employees}

The Supervisory board members appointed by the employees had the same rights as other members of the supervisory board. They had the right to participate in the decision making in the Supervisory board, the right to exercise supervision over the management of the shareholder company who is performed by the Board of directors, undertaking the board right of inspection and the possibility of checking the books, documents and record and the existing amount of the stocks and the commodities. For their work they were entitled to annual prize the same as the other members of the Supervisory board. ${ }^{x x x i i}$

Members of the Supervisory board appointed by the employees and other members of the Supervisory board had a duty to perform functions in the interest of the shareholders and the employees, as well as their obligation to work with care and diligence. They are responding to the company for the damage caused as a solid obligators with the other members of the Supervisory board in case of violation of its obligations, of course if they can prove that they acted with care and diligence. This commitment continues to apply, after the termination of the membership in the Supervisory board. 


\subsection{Participation of Employees in the Management Board in Public Company}

The Company Law envisaged a possibility for Republic of Macedonia to establish limited liability companies and shareholder companies in state ownership. xxxii

Board of directors as a management body could have at least five members. This management committee was composed of representatives of the owner of the share, the shareholders, employee representatives and members who were appointed because of their expertise. Employees could be represented by a maximum of one third of the members of the board. Employee representatives are appointed upon proposal at the Council of employees. All members of the board, including employee representatives where appointed by the Government of Republic of Macedonia. ${ }^{\text {xxiv }}$

\section{Company Law from 2004}

The Law on Trade Companies by $2004^{x \times x v}$ provides the basic legal framework for the type of entrepreneur, the manner and forms of its institutionalization in the company or as a business entity which will be implementing the business venture of the enterprise founders (investors). This law regulates and issues the management company and the types of bodies management of the company.

Unfortunately, the Company Law of Republic of Macedonia from 2004 regarding the issue of the employee participation in the management of a shareholder company had returned one step back. This law contains no provisions governing the issue of participation of employees in the management of a shareholder company even as an optional opportunity which existed and was established by Article 303 from the Company Law in 1996.Company Law from 2004 with the Article 342 paragraph 4 provides that: " The participation of employees in the company's management will be regulated by a special law", which law, to this point has not been adopted yet.

Adoption of a Law (Law/s for promulgation and amending/s), which will regulate the issue at participation of employees in the management of a shareholder company and the manner of its implementation will certainly contribute to greater integration of employees in achieving of the business of the corporation, consistent and satisfying of their rights and interests. This section require editing the questions for the right to join, his compulsion or faculty as an opportunity that will have to be regulated by the statute of the company, the size of the membership at bodies managing in the company, rights, obligations, responsibilities of representatives of the employees, questions to protect their employment, termination of the membership in the managing bodies. In case of accepting a solution for the regulation of the participation of employees in the managing bodies in the shareholder companies, they should think for existence of the independent non - executive members in the managing bodies in the shareholder companies in Republic of Macedonia.

Of particular importance is the arrangement for the issue of appointing and dismissing the representatives of the employees in the management body in the shareholder company. These representatives has to be appointed and dismissed by the representative body of employees. For this it needs to be done an amendment in the Law of Labor Relations from 2005 in Macedonia and in this law to settle the issue of the representative body of the employees in the company and to regulate all issues. From the solutions from the European legislative this body could be organized as form of a Workers council for the employees.

\section{Concluding Remarks}

Participation of employees in the management of a shareholder company is a question that comes as a part of a broader concept of participation of the employees in the enterprise (company) and social democracy. Because of this the company employees are eligible to participate in making decisions that are relevant to their position in the company and that this decisions may affect their rights and interests.

Republic of Macedonia is a country that builds its social political and economic regulation of relations in accordance with the known civilized and democratic values and in this way the fundamentally normative law provides the legal base for setting the issue of participation of employees in the management in the company. In this direction is the provision of the Article 58, paragraph 1 of the Constitution of Repulic of Macedonia ${ }^{\text {xxvi }}$ which stipulates that ownership and labor are the basic for management and participation in the decision - making.

At this point Republic of Macedonia needs to regulate the issue of participation in the bodies of management in the shareholder company. The question of organization and operation of the management bodies of the company is where it should be required, or to provide part of the possible solution for the participation of employees in the management of the shareholder company or in the managing and supervisory bodies of the shareholder company. For full editing of this issue will be necessary to made appropriate amendments to the Company Law from 2004 regarding the provisions governing the issue of the bodies managing in the company, both in the one - tier and in the two - tier management system. These provisions in the law are to settle the issue of participation of employees in the management bodies in the shareholder company. In this part of the law it should be regulated also the issue of the right of the membership and the size of the membership of the bodies managing the company, rights, obligations, responsibilities of the employee representatives and the issue of protection of their employment, termination of the membership of the managing bodies or to regulate all issues of material, legal and institute character. In this section will be required to settle the question of the further existence of the independent non - executive members of the management bodies in the shareholder company, and with institutionalizing the participation of the representatives of the employees in the managing bodies in the company. Furthermore it will be needed to settle the issue of the body (work council) that will conduct the appointment and dismissal of an employee representative and the issue should be regulated by the law for Labor relations from 2005. 


$$
\begin{array}{r}
\text { ISSN } 2321-1091 \\
\text { JoIume } 10 \text { Number } 2 \\
\text { Journal of Social Sciences Research }
\end{array}
$$

This regulation of the participation of the employees in the management of a shareholder company is crucial for the relations between the capital and the labor because this relation is relation of conflict of interests. In this way we can achieve a batter state of their relationship, which means achieving business enterprise and satisfying the interests of the investors (shareholders), and subsequently the economic and social rights and interests of the employees. On the other hand Republic of Macedonia doesn't have yet enough experience and practice on the issue of employee participation in the managing of the shareholder company.

The politics (the Government) as soon as possible should approach the concept of building a systematic solution of relations in the regulation of this issue. In any case, during the preparation of the concept of the relationship between labor and capital, should be taken into account the experience in the countries of the European union and the European union acts governing the issues of employee participation in the management and in the decision - making through information, counseling and co - decision and participation in the management and supervision of the companies. The capital shouldn't take the labor as his opponent and shouldn't view on him as factor from which his force and power are decreasing. Rather labor should be accepted as factor which increases the strength of the both sides (the owners and the employees). Capital and labor both are the cause and effect in the relationships in the realization of the business, together they create profit for the company, due to which both the first and the second should be rewarded for what they produce. If this issue is established that will achieve better economic results and better benefits not only for the employees and the owners but also for the society as whole.

We hope that in this work we were able to highlight the key aspects related to the issue of participation of the employees in the managing of the shareholder company according to the legislation in the Republic of Macedonia, in which we also outlined the issues to be further regulated in the Companies Law from 2004 and the Labor Law from 2005, with a main objective on the employees to get the place they deserved in the relationship between the labor and the capital. We expect that this work will cause an additional incentive for further considerations of this matter by the professional and scientific community.

\section{REFERENCES}

${ }^{1}$ Directive of the Commission 2001/86/EC from $8^{\text {th }}$ of October 2001 for Complementing the Statute of the European Company in Relation of the Participation of the Employees, Article 2, under (x)

${ }^{1}$ Fifth Directive is based on Article 54 (3) (g) of the Treaty and the EEC is about the Structure of the Companies and the powers and obligations of their organs. (The proposal for this directive was submitted by the Commission to the Council on 19 August 1983, the Directive has not been adopted yet)

${ }^{1}$ lbid, the Fifth Directive, Article 2

1 Directive of the Commission 2001/86/EC from $8^{\text {th }}$ of October 2001 for Complementing the Statute of the European Company in Relation of the Participation of the Employees; Article 2, under (k)

${ }^{1}$ Dr Milan Nedkov and Dr Tito Belicanec, Pravo na Drustvata (Company Law), book II, page 653

${ }^{1}$ Ibid

${ }^{1}$ About the Law on Trade Companies by 1996, its Meaning, Principles, Structure, Composition and the like, see more Dr Milan Nedkov, Dr Tito Beličanec, Dr Elena Gradiska Lazareska, Pravo na Drustvata (Company Law), Book I, pages 96 111

Law on Trade Conpanies ("Official Gazette of RM" No.28/1996, 7/1997, 21/1998, 37/1998, 63/1998, 39/1999, 81/1999, 37/2000, 31/2001, 50/2001, 61/2002, 4/2003 and 51/2003)

${ }^{1}$ Dr Milan Nedkov, Dr Tito Beličanec, Dr Elena Gradiska Lazareska, Pravo na Drustvata (Company Law), Book I, page 97 ${ }^{1}$ Ibid

1 Law on Trade Conpanies (“Official Gazette of RM” No.28/1996, 7/1997, 21/1998, 37/1998, 63/1998, 39/1999, 81/1999, 37/2000, 31/2001, 50/2001, 61/2002, 4/2003 and 51/2003), Article 303, Paragraph 2

1 Ibid, Article 303, Paragraph 3

${ }^{1}$ Ibid, Article 303, Paragraph 2

${ }^{1}$ Ibid, Article 305, Paragraph 1

1 Ibid, Article 305, Paragraph 4

${ }^{1}$ Ibid, Article 310

${ }^{1}$ Ibid, Article 306

${ }^{1}$ Ibid, Article 307, Paragraph 5

1 Ibid, Article 306, Paragtaph 3

1 Ibid, Article 306, Paragraph 3

1 Ibid, Article 321, Paragraph 2 
1 Ibid, Article 315, Paragraph 1

${ }^{1}$ Ibid, Article 314, Paragraph 1 and 2

${ }^{1}$ Ibid, Articles 309, 312, 313 and 320

1 Ibid, Article 334, Paragraph 3 and 5

${ }^{1}$ Ibid, Article 334, Paragraph 3 and 4

${ }^{1}$ Ibid, Article 335

${ }^{1}$ Ibid, Article 336, Paragraph 1 and 3

1 Ibid, Article 339

${ }^{1}$ Dr Milan Nedkov and Dr Tito Belicanec, Pravo na Drustvata (Company Law), book II, page 690 and 691

1 Ibid, page 691

1 Ibid, page 691

${ }^{1}$ Law on Trade Companies ("Official Gazette of RM" No.28/1996, 7/1997, 21/1998, 37/1998, 63/1998, 39/1999, 81/1999, 37/2000, 31/2001, 50/2001, 61/2002, 4/2003 and 51/2003 and 70/2013), Article 660, Paragraph 1

1 lbid, Article 666

1 Law on Trade Companies (“Official Gazette of RM” No.28/2004, 84/2005, 25/2007, 87/2008, 42/2010, 24/2011, 166/2012,70/2013, 119/2013, 41/2014, 138/2014, 88/2015, 192/2015 and 6/2016),

${ }^{1}$ Constitution of Republic of Macedonia from $17^{\text {th }}$ of November 1991, Article 58 paragraph 1

\section{Bibliography}

1.D-r. Milan Nedkov, D-r Tito Belicanec and D-r Elena Gradishki - Lazarevska "Company Law", book I, "Sigmapress", Skopje , 2003;

2.D-r Milan Nedkov and D-r Tito Belicanec, "Company Law”, book II, "Sigmapress", Skopje, 2008;

3.D-r Milan Nedkov, D-r Tito Belicanec and D-r Elena Gradishki - Lazarevska, "Company Law”, "Digi Print”, Skopje, 2009;

4.D-r Barbic Jaksa, " Company Law", book I, general part, "Organizator", Zagreb, 2008;5.D-r Barbic Jaksa "Company Law", book II, Capital companies, "Organizator", Zagreb, 2007;

6.Teofil Tomanovik and D-r Zoran Mihajlovski,"Colective contracts” , Theory and Practice "Selektor”, Skopje, 2010 7.Constitution of Republic of Macedonia from $17^{\text {th }}$ of November 1991;

8.Law for Labor Relations ((“Official Gazette of RM” No. 62/05, 106/08, 161/08, 114/09, 130/09, 149/09, 50/10, 52/10, 124/10, 47/11, 11/12, 39/12, 13/13, 25/13, 170/13, 187/13, 106/14, 113/14, 20/15, 33/15, 72/15 и 129/15);

9.Law on Trade Companies (“Official Gazette of RM”, No. 28/96, 7/97, 21/98, 37/98, 63/98, 39/99, 81/99, 37/2000, 31/2001, 50/2001, 61/2002, 4/2003 and 51/2003);

10.Law on Trade Companies (“Official Gazette of RM" No. 28/04, 84/05, 25/07, 42/10, 24/11, 166/12, 70/13, 119/13, 170/13, 41/14, 138/14, 88/15, 192/15 and 6/16);

11.Commission Regulation ( European commission) number 2157/2001, from $8^{\text {th }}$ of October 2001, Act of the European company (SE);

12.Directive of the Commission 2001/86/EC from $8^{\text {th }}$ of October 2001 for Complementing the Statute of the European Company in Relation of the Participation of the Employees;

13.Fifth Directive based on the Article 54 (3) (e) form the Convention EEC which is for the Structure of the Shareholder Company, the Authorization and the Obligations of their Organs;

14.Convention No. 87 from the International Labor Organization for the Freedom of Associating and Protecting the Right for Organizing from $1948 \mathrm{yr}$.;

15.Act No.143 from the International Labor Organization for the employee representatives from 1971. (The act is for Protecting and the Assets that should be provided for the Employee Representatives in the Company) 


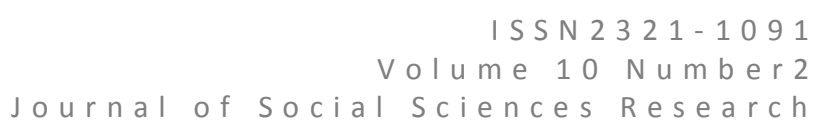

\section{Author biography with Photo}

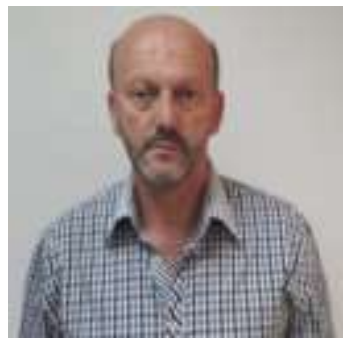

Ljupcho Petkukjeski is a doctor of sciences in the field of Business Law from The St. Cyril and Methodius University Skopje. Now he is state counselor for policy analysis and coordination at The General Secretariat of the Government of the Republic of Macedonia. He was a member of several working groups for drafting laws such as Law on Judicial Council, Law on Advocacy of the Republic of Macedonia before the European Court of Human Rights, Law on execution of judgments of the European Court of Human Rights, Law on the Attorney General of the Republic Macedonia and other laws. Also he worked as member and alternate member of the secondary commissions for deciding in administrative procedure in second instance. At the School of Law at the University American College Skopje he is engaged as a Adjunct professor on the subjects Administrative Procedural Law, Labor Law and Commercial Law.

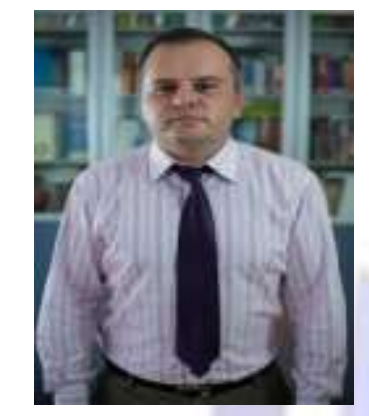

Marko Andonov is a doctor of sciences in the field of Business Law. His narrower subject of interest are Company Law, Securities Law as well as Labor Law. In 2009 he was elected as an Assistant Professor at the School of Law within the University American College Skopje. In 2013, Marko was elected for dean at the same School, and in 2014 he was also elected as an Associate Professor. His previous professional career is related with the Macedonian Securities and Exchange Commission. Dr. Andonov has participated in creation of several bylaws that derives from the Macedonian Securities Law. Also, he was a member of the working group for the Law on Investment Funds. Among the other academic and professional activities he is appointed as a coordinator of the Commercial Law module in the Academy for judges and prosecutors of the Republic of Macedonia.

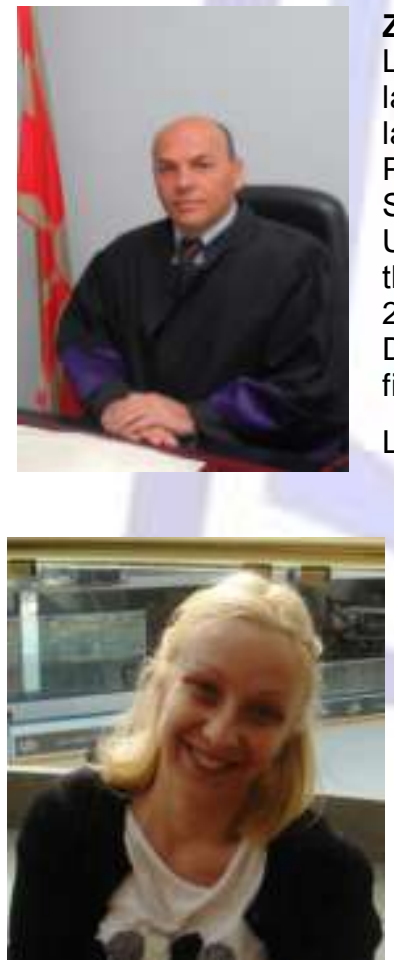

Zoran Mihajloski is a doctor of legal sciences. His narrow specialty are Labor Law and Business Law. He worked as a judge in the Court of Appeal in Skopje, in the specialized department for labor disputes as chairman of the Council for specialized labor and head of the department of labor disputes. He is elected for constant educator in the field of Labor Law and Civil Law Procedure in the Academy for judges and public prosecutors of the Republic of Macedonia. From September 2010 he was appointed as Assistant Professor at the School of Law within the University American College Skopje. In July 2014 he was appointed as Associate Professor at the same University. He has published his first book named "Collective Agreements" in 2007. In 2010, Zoran Mihajloski has published his scientific works named "Legal status of the managers". During his work, Zoran has published number of scientific and expert papers and articles in the field of Labor

Law and Business Law.

Kate Trajkova holds a PhD in the field of Management from The St. Cyril and Methodius University Skopje. At the School of Law at University American College Skopje, she is engaged as Adjunct Teacher on undergraduate and graduate studies in the field of Human Resource Management and Labour Law. Her teaching and research areas are also related with the Corporate social responsibility. Kate Trajkova has published numerous articles in the field of HRM. She has attended a number of seminars, trainings and conferences in the country and abroad 


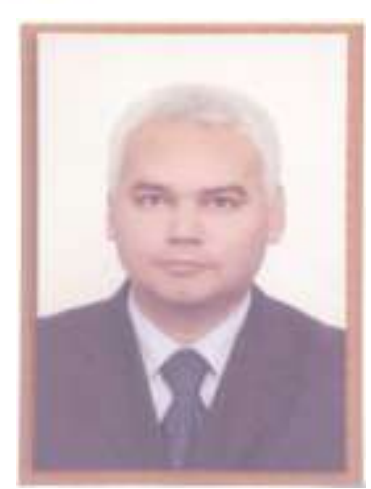

Samir Latif is the Director of the USAID Low Emissions Development and Clean Energy Investments Project and has more than 25 years of experience in business environment reform, business law, management and public/private sector capacity building in Macedonia.

In the past 21 years, Samir Latif has worked in progressively senior positions on various USAID projects in Macedonia dealing with business, economic, energy, legal and financial issues. He has been intimately involved in the processes that have led to reforms and progressive changes in the legislative and institutional framework in Macedonia. Subject areas of reform have included company, securities, bankruptcy, business registration/one-stop shop laws, energy, public procurement and related systems implementation, as well ADR, intellectual property, court and judicial restructuring; and NGO and SRO development including the development of their professional standards and codes.

Mr. Latif has a PhD in Business Law and since September 2006 is a visiting professor on the MBA studies at the American University in Skopje. 